\title{
Migration history in South Africa as a lens for interpreting God's mission: Towards a challenge for churches to embrace migrants
}

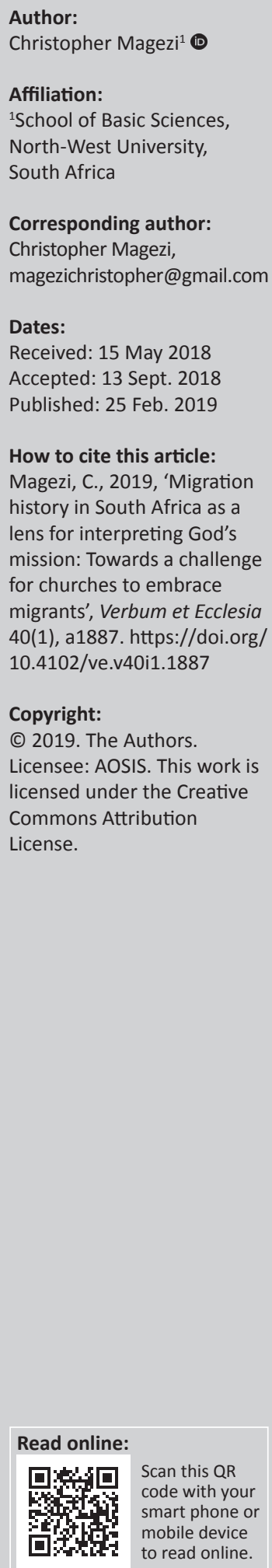

\begin{abstract}
This article challenges the church to embrace migrants by presenting migration history in South Africa during the era of European explorers as a lens for interpreting God's mission. In avowing the aforementioned, it argues for migration history of the European explorers to South Africa as the way God has used in establishing the church in South Africa. However, in view of the subsequent colonialism and slave trade in South Africa that emerged from the period of European explorers, this article recognises the conception of slave trade and colonialism during the era of European explorers as an evil act. Notably, in bringing Joseph's forced migration to Egypt as a theological lens to interpret some sinful acts that were embedded in the migration of European explorers to South Africa that also resulted in the establishment of the early church in South Africa, it contends that God's purpose and plans are not frustrated or thwarted by human sin. God, in his grace and love to reach his remnant people with the gospel, utilises various migrations of European explorers to South Africa (regardless of how sinful they are) to advance his kingdom to South Africa. The notion of migration history in South Africa as a lens for interpreting God's mission is utilised to challenge the churches to embrace migrants because God uses migration or migrants to advance his kingdom to all the earth. The article concludes by calling the church to embrace all migrants because humankind are usually unacquainted with the particular migrants that God is utilising to advance his kingdom.

Intradisciplinary and/or interdisciplinary implications: This article outlines theological research agenda for migration history in South Africa as a lens to interpret God's mission. It considers migration history in South Africa during the era of European explorers as a tool that God used to advance his kingdom. As such, it is a theological interdisciplinary article integrating church history and mission. The contribution of this article lies in establishing the emergence of the early church in South Africa as a result of migration, which it utilises as a challenge for churches to embrace migrants.
\end{abstract}

\section{Introduction, background and premise of the study}

There is a rapid increase in the movement of people from their place of 'origin to a destination, or from a place of birth to another destination across international borders' (Skeldon 2013:2). The International Organization for Migration (IOM) (2015a) presents a penetrating picture of the extent of international migration as a serious contemporary issue, which the international community cannot afford to ignore. It states that:

... the number of international migrants worldwide has continued to grow rapidly over the past fifteen
years reaching 244 million in 2015 up from 222 million in 2010 and 173 million in 2000. (p. 1)

Likewise, Martin (2013:2) states that from 1980 to 2010, the number of international migrants has increased by 117 million. In 1980, the number of international migrants was 103 million, which increased to 220 million by 2010. Furthermore, Martin (2013:2) and the United Nations Department of Economic and Social Affairs (2013) report that 'the number of international migrants increased from 220 million to 232 million by 2013'. Martin (2013:2) estimates that the number of international migrants is most likely to reach 400 million by 2050. In both confirming and magnifying the extent and gravity of the issue of international migration, the IOM (2014:1) reports that 'approximately one in seven people are migrating every day'. However, when people move from their countries of origin to their preferred countries of destination for various reasons, they are confronted with multifaceted and complex challenges that the church as a community of God is sanctioned by God to address (Magezi 2017; Snyder 2012). 
Many scholars (Adepoju 2006:87; Castles, De Haas \& Miller 2009:5) observe that although international migration has been ongoing in different parts of the world, its recent patterns have changed because of Europeans explorers and subsequent colonialism. Adepoju (2006:87) notes that 'different patterns, directions and motivations of migration have been severely affected by the colonial experience, which in turn, influenced economic, social cultural, political and demographic development'. In addition, Castles et al. (2009:5) state that 'migration took on a new character with the beginnings of European expansion from the 16th century'. These scholars affirm the view that European explorers and colonialism are migration phenomena that changed the global patterns of migration in migration history. The African Union (2006:4) considers migration discussion on the African continent on the basis of three periods: pre-colonial, colonial and post-colonial periods. Substantiating these views, the IOM (2004:10) notes that with the coming of colonialism about 500 years ago, the global shape of migration changed drastically because there were now new patterns of migration. The IOM asserts the consensus amongst historians regarding the age of European explorers and colonialism as the turning point of migration history. The IOM (2004) declares that:

Migration historians agree that a crucial point in the history of migration occurred about 500 years ago with the voyages undertaken by European explorers that led initially to the discovery of new worlds such as the Americas and Asia, and then on to the development of colonial endeavours. (p. 10)

Nevertheless, whilst the previously mentioned conception of the global history of migration is a reality, it also follows that it was during the era of European explorers that we have seen the advancement of God's kingdom to other continents and countries in the world (cf. Bosman n.d.:1-11; Njoku 2007:218-257; Paas 2017; Sundkler \& Steed 2000). Indeed, this is consistent with the Great Commission in Matthew 28:1620 , in which Jesus' followers were commanded to extend the Kingdom of God to the rest of the world. That is, Christ accomplished the salvation of humankind and inaugurated the Kingdom of God, in which he called people who believe in his redemptive acts to be his instrument in extending his salvation and inaugurated kingdom to all nations in words and deeds. This implies that the followers of Jesus Christ were to migrate with the gospel to the various parts of the world. In light of this background, this article examines migration history in South Africa during the era of European explorers as a lens for interpreting God's mission in a manner that challenges the churches to embrace migrants rather than excluding them.

The structure of the articles is as follows: the first section disagrees with historians who tackle the history of migration in South Africa by commencing from the age of European explorers. It argues by citing Bantu migration as the largest mass movement of people to South Africa that there was migration in South Africa during the pre-colonial period. The section then proceeds to delve into the migration history in South Africa during the era of European explorers. The second section provides the interconnection between the migration history in South Africa during the period of European explorers and the advancement of God's kingdom to South Africa. Because of subsequent colonialism and slave trade as a result of the migration history of European explorers (Rodney 1973), the third section uses Joseph's forced migration to Egypt (in Gn 37-50) as a theological lens to interpret the sinful acts that were embedded in the migration of European explorers to South Africa that also resulted in the establishment of the early church in South Africa. The article concludes with the view that migration history in South Africa (during the era of European explorers) as a lens for interpreting God's mission should operate as a challenge for churches to embrace migrants because God uses migration or migrants to advance his kingdom and bring salvation to all people and nations.

\section{The history of migration in South Africa during the era of European explorers \\ The history of migration in South Africa during the pre-colonial period}

In their book entitled Views on Migration in Sub-Saharan Africa: Proceedings of an African Migration Alliance Workshop, Cross et al. (2006:4) noted that 'at the beginning of the 21st century, governments are beginning to address migration as a priority in Africa and worldwide'. The reason for that special focus on a migration crisis in Africa is the 'fears of the destabilising consequences of human flows at different scales' (Cross et al. 2006:4). Furthermore, an 'uneasy recognition is emerging that the tide of human movement from the developing world to the developed world is on the rise everywhere' (Cross et al. 2006:4). By implication, Cross et al. demonstrate that migration in Africa was already an existing phenomenon prior to the 21st century, although special attention to migration in Africa is given because of the large-scale movement of people within African nations and abroad.

Castles et al. (2009:xi) concur with Cross et al. in their assertion that from the beginning 'human beings have always moved in search of new opportunities, or to escape poverty, conflict or environmental degradation'. In agreement, Baker and Aina (1995:11) argue that migration in Africa is not a new phenomenon, although its form and dynamics have changed over time. These periodic migrations were both internal and international movements because of the 'political, economic, religious and security situation, and demographic factors' (Adepoju 2006:87). In a different way, Aina (1995:41) argues that the reasons for migration in Africa ranged from factors such as 'wars of conquest, responses to ecological and other disasters, to the peaceful and gradual occupation of vacant lands by some groups'. Although there is an increase of Africans who move across their international borders and beyond because of the above-mentioned reasons, one has to bear in mind that the African continent was separated from the rest of the world before humanity's technological advancement of the past centuries (Thompson 2000:3). 
However, the separation of the African continent from the rest of the world does not suggest that there was no migration within the African continent before its connection to other continents. With this in mind, before we examine the history of migration in South Africa during the era of European explorers, we are cognisant of the fact that migration in Africa commenced before the era of European explorers. Thompson (2000:6, cf. McGlinn n.d.:1) argues that the modern Khoekhoe, whom the 'white settlers called Bushmen and Hottentots', are considered to be the earliest people to live in Southern Africa, including modern-day South Africa. The Khoekhoe 'were small people with light brown or olive skins' who survived by hunting and gathering. The Khoisan people constitute 'a high proportion of the genes of the Coloured people, who constitute $9 \%$ of the population of the modern Republic of South Africa' (Thompson 2000:6, cf. McGlinn n.d.:1). McKenna (2011: xiii) and McGlinn (n.d.:1) concur with Thompson by arguing that the San and Khoekhoe people were the original inhabitants of Southern Africa before Bantu migration. That is, there was a possible collision of people around $100 \mathrm{CE}$ when Bantu-speaking people 'migrated southward through Africa' (McKenna 2011:xiii). Thus, in underscoring the backdrop of migration on the African continent, Grollemund et al. (2015:13296-13301) view Bantu migration as the earliest major movement of people in Africa.

Thus, although we are dealing with migration history in South Africa during the era of European explorers, we disagree with historians who begin their history of South Africa by offering (Thompson 2000):

a brief reference to the voyage of Vasco da Gama round the Cape of Good Hope in 1497-1498 and then rush on to the arrival of the first white settlers in 1652. (p. 1)

In our view, those historians who start their South African history from the arrival of pioneer Europeans are only concerned with emphasising the role of Western capitalism in shaping Southern Africa, particularly South Africa. In so doing, these historians are undermining the 'processes that shaped society before Europeans began to intrude in the region' (Thompson 2000:1). However, for the purpose of this article, we will focus on migration history in South Africa during the era of European explorers as the period associated with the emergence of Christianity in South Africa.

\section{International migration during the era of European explorers and subsequent colonial period in South Africa}

It is important to note that although there has been internal migration between the Bantu-speaking people of South Africa and its native people (i.e. the Khoekhoe), South Africa remained isolated from the rest of the world until the 15th century when the first Europeans arrived in South Africa (Thompson 2000:31). The first European to enter South Africa was the Portuguese explorer Vasco da Gama, who had his voyage around the Cape of Good Hope in 1497-1498 (Thompson 2000:1; cf. Boorstin 1983:177; McKenna 2011:15ff). Boorstin (1983:177, cf. Thompson 2000:32) affirms this notion saying that the voyage of Vasco da Gama 'changed the course of both Western and Eastern history' because Africa, particularly South Africa, was now connected to the rest of the world. Although the exact number of Portuguese who arrived in South Africa after this voyage is unknown, it is possible that many Portuguese might have entered modernday South Africa to explore the country and expand their businesses. From the end of the 16th century, many Europeans arrived in South Africa to trade with the Khoikhoi. Thompson (2000) highlights that:

By the end of the sixteenth century, Dutch, English, French, and Scandinavian merchant mariners were also beginning to use the sea route to Asia. From time to time, they landed on the Cape peninsula to take in fresh water and barter sheep and cattle from the local Khoikhoi pastoralists in return for iron and copper goods. In 1620, the English government ignored a suggestion of an English ship's captain that it should annex 'the Cape'. (p. 32)

The above quotation highlights that apart from the Portuguese migration, there were many migrations from other continents to South Africa. Nonetheless, in the quest to understand the history of international migration in South Africa, one should note that the white settlement in South Africa that took place in the Cape under the Dutch East India Company fuelled immigration of people from other nations to South Africa, especially Europeans (cf. Campbell 1897:4ff; Mckenna 2011:22). The Dutch East India Company was founded in 1602 by the Dutch Republic, and by that time it had grown to be 'the world's greatest trading corporation'. Hence, to expand its business to Africa, the Dutch East India Company assigned Jan van Riebeeck (accompanied by 125 men) to sail to the Cape and seize Table Bay in order 'to serve a specific and limited role as a link between the Netherlands and their eastern empire, centred on Batavia, Java' (Thompson 2000:33).

In 1657, the Dutch East India Company shipped a number of slaves, who were raided from a 'Portuguese vessel bound from Angola to Brazil' (McKenna 2011:22; cf. Thompson 2000:36), to the Cape to assist the company with various manual works. Thompson (2000:33) states that the Cape colony developed 'a degree of autonomy and an unforeseen dynamic' to the extent that 'by the time Van Riebeeck handed over the command to his successor in 1662, the colony had become a complex, racially stratified society'. However, after this first movement of slaves to the Cape, the Cape colony continued to depend on slave labour to sustain its demand of labour (cf. Ross 1983; Shell 2012; Watson 1991; Worden 1985). Many of these slaves were imported from 'Mozambique, Madagascar, Indonesia, India, and Ceylon (Sri Lanka), including a large minority of Muslims' (McKinn n.d:1; Thompson 2000:36). There were approximately 14747 slaves (9046 men, 3590 women and 2111 children) in 1793 (McKinn n.d:1; Thompson 2000:36). Storey (2017:2) notes that after the abolition of slave trade in the 1830s, there were huge immigrations of foreign people to South Africa as indentured labourers. Storey (2017) avows that:

...the abolition of slavery in the 1830 s resulted in the importation of 452,000 indentured laborers from India by the time of the First World War. In the same time period, 111,000 indentured Indians 
migrated to the French island of Reunion, whilst 152,000 migrated to Natal. Population movements attributable to the problems of colonialism - and the consequent social and political tensions formed the key theme of the region's history in the century between the Napoleonic Wars and the First World War. (p. 2)

Furthermore, one has to recognise the existence of many French Huguenots (Protestants) who came to join the Dutch in 1688 (McKinn n.d.:5). These French Huguenots were escaping religious persecution under the Catholic King Louis XIV (McKinn n.d.:5).

Thus, the colonialisation of South Africa that began in 1652 at the arrival of Van Riebeek (and his team) resulted in the slavery and forced labour of many Africans and beyond. In the wider argument of his book entitled Khoikhoi and the Founding of White South Africa, Elphick (1985) underscores that the arrival of Van Riebeek and many other Europeans (i.e. British and French people) in South Africa destroyed the independence of the indigenous South African people. Thompson (2000) concurs with Elphick by describing the way the Khokhoi people failed to resist the Dutch invasion:

By 1713, the indigenous pastoral society of the southwestern corner of Africa was disintegrating. Whites were in control of the fertile territory below the mountain escarpment extending fifty miles north and forty miles east from Cape Town. The Khoikhoi had been unable to withstand the invasion of the Dutch East India Company and its settlers. They had lost most of their livestock - their most valued possessions: the records of the company show that between 1662 and 1713 it received 4,363 cattle and 32,808 sheep from the Khoikhoi. (p. 38)

Furthermore, it is reported that the British were amongst the earliest white people to migrate to South Africa because they were already present in 1795 (Campbell 1897:1-14; cf. Thompson 2000:51ff). This is because in 1795 the British went to battle with the Dutch at Muizenberg, and the Dutch lost the Cape to the British. However, the Cape was returned to the Dutch after the peace of Amiens in 1802, and then repossessed by the British again in 1806 after the battle of Blaauwberg. This ownership of the Cape was then sealed by the Anglo-Dutch Treaty of 1814 (Campbell 1897:1-14; cf. Thompson 2000:51ff). Given this, we are of the opinion that the commencement of the white settlers in 1652 resulted in the influx of people from many countries into South Africa, including the Europeans who migrated slaves from other countries into South Africa as cheap labour for their industries.

\section{International migration and the church in South Africa}

Many church historians (cf. Bosman n.d.:1-11; Njoku 2007:218-257; Paas 2017; Sundkler \& Steed 2000) are of the opinion that Christianity was introduced to Africans by the European missionaries who migrated to Africa at a particular point in the history of migration. Njoku (2007:219) substantiates this conception, affirming that 'the major external agents for the introduction of Christianity to Africa were European missionaries' who migrated from Europe to Africa with the redemptive message of Jesus Christ. In paying particular attention to the history of Christianity in South Africa, Bosman (n.d.:5) affirms that one of the main aims for the establishment of the Dutch trading point in the Cape of Good Hope in 1652 was to reach the indigenous population living on the southernmost tip of Africa with the Gospel of Jesus Christ'. In saying this, he also notes that the evangelistic purpose was not at the heart of the establishment of the Cape, 'especially taking into consideration the half-hearted efforts of the Dutch Reformed Church to convince the indigenous Khoikhoi tribe to convert to Christianity' (Bosman n.d.:5). The reason is that 'the Khokhoi were very difficult to deal with'. 'The Hottentot clans near Table Mountain were always at war with one another, and they were perpetually stealing from the colonists' (Wirgman 2012:18).

Wirgman (2012:17) substantiates that one of the aims of the Dutch East India Company was to evangelise the indigenous people of the southernmost tip of Africa. He further adds that the expedition of the Dutch East India Company led by Van Riebeeck was constituted of 181 exclusive officers. Because of the Company's interest to reach the indigenous people with the gospel, a minister (catechist) accompanied Van Riebeeck's team so that he could conduct the services on a regular basis. With this in mind, the mission of Van Riebeeck by the Dutch East India Company to set up the flag of the Netherlands and to establish a colony at Table Bay in the Cape of Good of Hope resulted in the emergence of the first church in South Africa (Wirgman 2012:17). It is important to note that most of the Dutch migrants who accompanied Riebeeck in his mission were members of the Dutch Reformed Church. In spite of the enmity that later intensified between the Dutch and the Khoikhoi (Hottentots), Van Riebeeck (and many other Dutch) tried to maintain a good relationship with the Khoikhoi people with the aim to reach them with the redemptive message of Jesus Christ. In this way, Van Riebeeck's intention to reach the indigenous people with the gospel was not isolated from that of the authorities who were conscious of the role religion has played in some of their colonies (Wirgman 2012:17). The first conversion in the Cape of Good Hope by the Dutch Reformed Church was done under the ministry of Van Riebeeck. Wirgman (2012) narrates the conversion of a Khoikhoi girl under Van Riebeeck's ministry as follows:

Van Riebeek brought up a Hottentot girl in his own house and taught her the Christian religion. She was baptized afterwards by the name of Eva, and married to a Dutch surgeon named Van Meerhof. The Company provided a bridal feast, and gave the bride a wedding present of $£ 10$. Van Riebeek held the view that the profession of the Christian religion placed black and white on the same level. (p. 18)

Given this, together with Wirgman (2012:18), we argue that although there were many negative reasons (i.e. the colonisation of Table Bay) for the migration of the Dutch to 
the Cape of Good Hope in 1652, one is justified to advance that the early Dutch had 'good desires to treat the natives well, and to bring them under the influence of a Christian civilization' ${ }^{1}$. It is from that time that the gospel advanced to other parts of South Africa, though with many challenges and successes. Nevertheless, we are aware that some of the Dutch Reformed Church members later on played a negative role by supporting the archaic apartheid system (Kritzinger 2013:2412-4265). However, this does not substitute the fact that the Dutch were the initial people to arrive with the gospel in South Africa, particularly in modern Cape Town. The Dutch Reformed Church denomination currently has extended to other parts of Africa.

After the arrival of the first missionaries in 1652, many missionaries from other European countries arrived in South Africa with the gospel (Olsen 2008:24ff). Elphick (2012:25; cf. Olsen 2008:24) recognises Johannes Theodorus van der Kemp as one of the European missionaries who migrated to South Africa with the purpose of advancing the Kingdom of God. Van der Kemp was a Protestant missionary of the London Missionary Society (LMS) who arrived in modern Cape Town on 31 March 1799, and ministered amongst the Xhosa people from 1799 to 1811 . He is regarded as the founder of Xhosa Christianity because of the great conversion of the Xhosas that God achieved through him (Elphick 2012:25). Despite many challenges he encountered amongst the Xhosas, Van der Kemp strove to reach the Xhosas with the gospel. For example, in the midst of Van der Kemp defending himself against the attacks of those who accused him of causing the drought in their territory, he continued to preach the Word of God and transformed many lives amongst the Xhosas (Wilson 1972:2). At this point, we argue that although some early Western missionaries conflated the gospel with their Western cultures and undermined African traditional world view by regarding it irrational and deemed other cultural values as barbaric, it is apparent that their migration to South Africa extended the Kingdom of God to South Africa in many and different ways (Vilhanová 2007:249-260, cf. Aguwa 2007:127-128; Bosch 1993:262; Setiloane 1976:89). It is through the migration of these Western missionaries that many churches, schools, hospitals and stores were opened to serve the mass of native Africans (Vilhanová 2007:249-260).

Given this, and the migration of the European missionaries and many others, South Africa was reached by the gospel to the extent that Christianity is currently one of the largest and dominant religions in South Africa (Rule 2002:87-96; Schoeman 2017:1-7). Hence, Vilhanová (2007) analyses that:

The third phase of the missionary movement in Africa, which started from the end of the eighteenth and continued throughout the nineteenth century, in twentieth-century Africa led to the dramatic expansion of Christianity called 'the fourth great age of Christian expansion'. (p. 249)

1.However, we are aware that this civilisation was also informed by white supremacy over black people (cf. Vilhanová 2007:249-260, cf. Aguwa 2007:127-128; Bosch 1993:262; Setiloane 1976:89).
This means that God in his grace and love to advance his kingdom to all nations caused the European missionaries to migrate to South Africa to preach the gospel so that his remnant people in South Africa could be saved.

\section{The interconnection between migration history in South Africa and the extension of God's kingdom as a challenge for churches to embrace migrants}

It is our firm conviction that migration history in South Africa during the era of European explorers has caused mixed reactions amongst scholars. Some scholars evaluate the era of European explorers negatively because of colonialism and subsequent slave trade that is embedded in the period of European explorers. For instance, in his book entitled How Europe Underdeveloped Africa, Rodney (1973) attributes the underdevelopment of contemporary Africa to colonialism. He argues that although European colonialism benefited Africa, it is apparent that, to a larger extent, colonialism and its outcomes such as slave trade developed Europe at the expense of Africa. In Rodney's view, the current situation of poverty and underdevelopment in Africa came into existence because of colonialism and its consequences. However, whilst Rodney's view is justified and held by many historians, we argue that the history of migration in South Africa can also be used to challenge churches to have a positive view of migration in a way that compels them to embrace people from other nations. Although the age of European explorers in South Africa has resulted in colonialism and slave trade, we discern that God used the migration of some European explorers to reach his remnant people in South Africa. The theological conception embedded in the history of migration in South Africa during the era of European explorers that resulted in the extension of God's kingdom resonates with Joseph's narrative of forced migration to Egypt. This theological conception is that God's plan and purpose 'is not thwarted by human sin, but rather advanced by it through his good grace' (Arnold 2009:361).

Here, we acknowledge the difference between Joseph's migration and the migrations of European explorers, which lies in the fact that Joseph's migration was a forced migration, whereas that of European explorers was a choice with mixed intentions, that is, to spread the gospel and the European civilisation that resulted in colonialism and slave trade. However, the similarity lies in the fact that God used human sin even in migration to advance his plans and purposes for humankind. In paying attention to the forced migration in Genesis 37-50, we argue that God used the sinful intentions of Joseph's brother to advance his plans and purposes for humanity. Joseph was sold by his brothers to the Midianite merchants, who migrated with him and sold him to the Egyptians, who oppressed Joseph in various ways (Gn 37:28). However, God in his divine providence saved Joseph in those incidences to further his redemptive purposes and plans for the world.

For instance, after Potiphar's wife (Potiphar was Pharaoh's official) failed many times to convince Joseph to lie with 
her, she made a false claim that Joseph wanted to lie with her. Because of that false assertion, Joseph ended up in prison (Gn 39). Nonetheless, God in his providence rescued Joseph from the prison to the second highest position in Egypt after Pharaoh by granting him the wisdom to interpret Pharaoh's dream (Gn 41). Pharaoh dreamed of seven fat cows and seven lean cows, which Joseph rightly interpreted to refer to seven years of good harvest and seven years of famine (Gn 41:15ff). Pharaoh was satisfied with Joseph's interpretation of his dream and placed Joseph in charge of the entire land of Egypt (Gn 41:41). When Joseph assumed power in Egypt, he improvised a solution to save the Egyptians from the approaching famine. However, in God's divine providence, the solution that Joseph improvised to combat the approaching famine in Egypt also saved Joseph's family, and God's redemptive purposes and plans for humankind. This highlights that in the midst of the forced migration of Joseph and all the various challenges he encountered in Egypt, it is apparent that God was using Joseph to save the physical descendants of Israel that God designed to utilise in accomplishing his redemption for Adam and his descendants (Gn 3:15 \& 12:3), while at the same time saving the Egyptians from famine. God achieved this through a number of ways, which are discussed below.

Firstly, at a point when famine was severe in the land of Canaan, Jacob heard that there was corn in Egypt and he sent his children to Egypt twice to buy food (cf. Gn 42 \& 43). Later on, Jacob, his whole family and livestock migrated to Egypt (Gn 46ff), where Pharaoh ordered Joseph to give his father (Jacob) and his family the best land of Egypt to inhabit, namely Goshen (Gn 45:16-18 \& 47:5ff). Thus, in God's larger purpose and plan, the migration of Joseph saved both the Egyptians and the tribe of Israel from dying from famine (Gn 50:19-21). Here it is important to note that Joseph's migration was a great blessing to the Egyptians to the extent that, at the second migration of Jacob's sons to Egypt (in which Joseph revealed himself to his brothers), Pharaoh was pleased to hear that Joseph's brothers had come to Egypt (Gn 45:16). It is possible that Pharaoh was pleased because of the blessings that Joseph's migration had brought Egypt. Given this, Pharaoh requested Joseph to give his brothers food and return to Canaan to bring their father (Jacob) and his belongings to Egypt to dwell in the best land of Egypt. $\mathrm{Jacob}^{2}$ migrated to Egypt with all his belongings, such as wives, children, livestock and tools, except land. ${ }^{3}$

Secondly, at the heart of Joseph's migration was God who used his migration to accomplish his redemptive plans for Adam and his descendants that he promised in Genesis 3:15

2.We are aware that Abraham was a wanderer and was in Egypt at some time (Gn 12) Isaac also wandered (Gn 26), Jacob too had to go to Haran and all Jacob's sons were wanderers too. The migration to Egypt which led to the Egyptian bondage from which God delivered them took place after many migrations by individuals.

3.God's involvement in the migration of his people is evidenced in the case of Jacob, where God promised to protect Jacob as he migrates to Egypt. That is, when Jacob was scared to move to Egypt with his family because of famine in the land of Canaan (Gn 46:1-4), God revealed himself to Jacob and assured Jacob of his protection as Jacob journeys and sojourns in the foreign land of Egypt. and Genesis 12:3. Joseph himself understood his migration from a redemptive perspective. Here, Joseph was conscious that 'what really survives' through his migration 'is the plan of redemption announced first to his great grandfather' Abraham (cf. Gn 12:1-3, 15, 17:1-16; Hamilton 1995:576). In other words, the migration of Joseph, Jacob and his family to Egypt was not accidental. In Genesis 15:13-14, God foretold Abraham about the certainty of the migration of his descendants to an alien land, in which they will be in slavery for 400 years, as well as the certainty their deliverance from that captivity. In this way, God in his grace and love intended to use the migration of Joseph to save people and thereby to accomplish his redemptive purposes and plans for humankind. Later on, Joseph himself understood that the sin of his brothers was used by God to advance his redemptive purposes and plans for all mankind that was first announced in Genesis 3:15 and renewed through Joseph's grandfather, Abraham (Arnold 2009:361; Cotter 2003:313). This implies that Joseph in Genesis 45:5-7 and 50:19-21 theologically understood that (Arnold 2009):

God's purpose is not thwarted by human sin, but rather advanced by it through his good grace. The hand of God is seen, not only in clearly miraculous interventions and revelations, but also in the working out of divine purposes through human agency, frail and broken, as it is. (p. 361)

In this way, Joseph's narrative of migration should be perceived as a theological lens to view the human sin embedded in the migration of European explorers to South Africa. Here, we argue that the migration history in South Africa during the era of European explorers should be viewed as a lens for interpreting God's mission because God has used various migrations to advance the gospel to Africa, particularly in South Africa. This understanding should lead churches, and consequently Christians, to have a positive view of migration in a manner that challenges them to embrace people from other nations. Embedded within the aforementioned conception is our theological conviction that migration does not happen by chance; instead, God was involved in the migration of the European explorers to fulfil his gospel promises and plans for humankind. This means that regardless of human sin that was intrinsic in the migration history of European explorers to South Africa and beyond, those migrations were intrinsically related to redemptive history and sovereignly planned, executed and carried out by God to advance his kingdom to South Africa and beyond (cf. Medeiros 2013:174). Having established the aforementioned, the individual and corporate factors for the migration of European explorers to South Africa may in this case also receive a more than human aspect in God's providential control of everything that has to do with human beings as he works out his plan to fulfil his promises. In other words, in arguing for migration history in South Africa during the era of European explorers as a lens for interpreting God's mission, we are challenging churches to embrace people from other nations because God is involved in their migrations that sometimes involve sin, pain and loss to accomplish his plans and purposes for humankind. Now, 
the church is challenged to embrace all foreign nationals because humankind are usually unaware of what God is doing with particular people at their doorsteps. That is, because people are usually unconscious of what the loving, gracious, omniscient and sovereign God is doing through people, migrants' receiving communities are called to be more receptive of people from other nations.

\section{Conclusion}

This article has challenged the church to embrace migrants by arguing that migration history in South Africa during the era of European explorers can be used as a lens for interpreting God's mission. It argued for migration of European explorers to South Africa as the way God has used in history to advance his kingdom to South Africa and beyond. However, in light of the subsequent colonialism and slave trade that emerged from the migration, this article recognised the conception of slave trade and colonialism as an evil act. Nevertheless, in using the theological conception of Joseph's forced migration to Egypt as a theological lens to understand the migration history of European explorers to South Africa, it advanced that God's purpose and plans were not frustrated or thwarted by human sin during the era of European explorers. Instead, in his grace and love to reach all people with the gospel, God has utilised various migrations during the era of European explorers to advance his kingdom to South Africa and beyond. In bringing this notion to bear on the current migration issue, we argued that the view of migration history of European explorers to South as a means God has used to advance his kingdom should operate as a lens for interpreting God's mission. This previously mentioned understanding should challenge churches to embrace migrants because God utilises migration to advance his kingdom. In other words, the notion of the migration history of European explorers to South Africa as a lens to interpret God's mission and to serve as a challenge for the churches and consequently Christians to be more receptive of people from other nations. Here, Christians are to embrace all people from other nations because they are usually unaware of what God is doing with particular people at their doorsteps.

\section{Acknowledgements}

The author thanks God for his provision of good health and strength from the commencement of this article to its completion.

\section{Competing interests}

The author declares that he has no financial or personal relationships that may have inappropriately influenced him in writing this article.

\section{Funding information}

This project was funded by the North-West University Faculty of Theology.

\section{References}

Adepoju, A., 2006, 'Leading issues in international migration in sub-Saharan Africa', in C. Cross, D. Gelderblom, N. Roux \& J. Mafukidze (eds.), Views on migration in SubSaharan Africa: Proceedings of an African Migration Alliance, pp. 25-47, HSRC Press, Cape Town, South Africa.

African Union, 2006, The migration framework policy for Africa. Executive Council Ninth Ordinary Session 25-29 June 2006, viewed 22 April 2018, from http://www. fasngo.org/assets/files/resources/EXCL276_IX__Strategic_Framework_for_ Policy_Migration.pdf

Aguwa, J.C., 2007, 'Mission, colonialism, and the supplanting of African religious and medical practices', in M.K. Asante (ed.), African studies history, politics, economics, culture, pp. 127-145, Taylor \& Francis, South Africa.

Aina, T. \& Baker, J., 1995, 'Introduction', in T. Aina \& J. Baker (eds.), The migration experience in Africa, pp. 11-25, Nordic Africa Institute, Uppsala.

Aina, T.A., 1995, 'Internal non-metropolitan migration and the development process in Africa', in T. Aina \& J. Baker (eds.), The migration experience in Africa, pp. 41-53, Nordic Africa Institute, Uppsala.

Arnold, B.T., 2009, Genesis: The new Cambridge Bible commentary, Cambridge Press, Cambridge.

Boorstin, D.J., 1983, The discoverers: A history of man's search to know his world and himself, Phoenix, London.

Bosch, D.J., 1993, Transforming mission: Paradigm shifts in theology of mission, Orbis Books, Maryknoll, MO.

Bosman, M., n.d., History of Christianity in Africa, viewed 28 August 2017, from https://www.pdfdrive.com/history-of-christianity-in-africa-e3092944.html

Campbell, C.T., 1897, British South Africa: A history of the colony of the Cape of Good Hope from its conquest 1795 to the settlement of Albany by the British emigration of 1819 (A.D. 1795-A.D. 1825), John Haddon \& Co, London.

Castles, S., De Hass, H. \& Miller, M.J., 2009, The age of migration: Internationa population movements in the modern world, 4th edn., Guilford Press, New York.

Cotter, D.W., 2003, Genesis - Berit Olam: Studies in Hebrew narrative and poetry, Liturgical Press, Collegeville, MN.

Cross, C., Gelderblom, D., Roux, N. \& Mafukidze, J., 2006, Views on migration in subSaharan Africa: Proceedings of an African Migration Alliance workshop, HSRC Press, Cape Town.

Elphick, R., 1985, Khoikhoi and the founding of White South Africa, Ravan Press, Johannesburg.

Elphick, R., 2012, The equality of believers: Protestant missionaries and the racial politics of South Africa, University of Virginia Press, Charlottesville, VA.

Grollemund, R., Branford, S., Bostoen, K., Meade, A., Venditti, C. \& Pagel, M., 2015 Bantu expansion shows that habitat alters the route and pace of human dispersals, viewed 27 August 2017, from www.pnas.org/content/112/43/13296.full.pdf

Hamilton, V.R., 1995, The book of Genesis chapters 18-50: The international commentary on the Old Testament, William B. Eerdmans, Grand Rapids, MI.

International Organisation for Migration, 2004, 'Migration and history, section 1.3', Essentials of migration management: A guide for policy makers, vol. 1, viewed 17 August 2017, from www.rcmvs.org/documentos/IOM_EMM/v1/V1S03_CM.pdf

International Organisation for Migration, 2014, Global migration trends: An overview, viewed 19 April 2018, from http://missingmigrants.iom.int/sites/default/files/ documents/Global_Migration_Trends_PDF_FinalVH_with\%20References.pdf

International Organisation for Migration, 2015a, Migration in the world: Slovak Republic. Migration for the benefit of all, viewed 22 September 2017, from www. iom.sk/en/about-migration/migration-in-the-world

International Organisation for Migration, 2015b, World migration report 2015 Migrants and cities: New partnerships to manage mobility, viewed 22 April 2018 , from https://www.iom.int/world-migration-report-2015

Kritzinger, K., 2013, 'The role of the Dutch Reformed Mission Church and the Dutch Reformed Church in Africa in the struggle for justice in South Africa, 1986-1990', Studia Historiae Ecclesiastica 39(2), 2412-4265.

Magezi, C., 2017, 'Migration crisis and the church: A response to lacunae and considerations for Christian ministry engagement', Verbum et Ecclesia 38(1), a1671. https://doi.org/10.4102/ve.v38i1.1671

Martin, P., 2013, 'The global challenge of managing migration', Population Bulletin 68(2), 1-15.

McGlinn, P., n.d., A brief history of South Africa to the end of the 19th century, viewed 09 April 2018, from https://courses.u3anet.org.au/wp-content/uploads/History/ History $\% 20$ of $\% 20$ South $\% 20$ Africa $\% 20$ to $\% 201900$.pdf

McKenna, A., 2011, The history of Southern Africa, Britannica Educational Publishing in association with Rosen Education Services, New York.

Medeiros, E., 2013, 'God scatters to gather through his people. A missional response to migrant churches', in S.T. Logan (ed.), Reformed means missional, pp. 173-188, Green Growth Press, Greensboro, NC.

Njoku, C.A., 2007, 'The missionary factor in African Christianity, 1884-1914', in O.U. Kalu, J.W. Hofmeyr \& P.J. Maritz (eds.), African Christianity: An African story, pp. 218-257, Department of Church History, University of Pretoria.

Olsen, B., 2008, 'An overview of translation history in South Africa 1652-1860', MA Thesis, University of the Witwatersrand, Johannesburg.

Paas, S., 2017, Christianity in Eurafrica: A history of the church in Europe and Africa, New Academia Publishing, Washington, DC. 
Rodney, W., 1972, How Europe undeveloped Africa, Bogle-L'Ouverture, London.

Ross, R., 1983, Cape of torments: Slavery and resistance in South Africa, Routledge and Kegan Paul, London.

Rule, S., 2002, 'Spirituality in South Africa: Christian beliefs', Hindu 1, 87-96.

Schoeman, W.J., 2017, 'South African religious demography: The 2013 General Household Survey', HTS Teologiese Studies/Theological Studies 73(2), a3837. https://doi.org/10.4102/hts.v73i2.3837

Shell, R.C.H., 2012, Children of bondage: A social history of the slave society at the Cape of Good Hope, 1652-1838. Wesleyan University Press.

Setiloane, G.M., 1976, The image of God among the Sotho-Tswana, Balkema, Rotterdam.

Skeldon, R., 2013, 'Global migration: Demographic aspects and its relevance fo development', Technical paper no. 2013/6, United Nations Department of Economic and Social Affairs, viewed 27 March 2018, from http://www.un.org/en/ development/desa/population/migration/publications/technicalpapers/docs/ EGM.Skeldon_17.12.2013.pdf

Snyder, S., 2012, Asylum-seeking, migration, and church, Ashgate, Farnham.
Storey, W.K., 2017, 'Southern Africa', 1914-1918 Online - International Encyclopedia of the First World War, viewed 02 March 2018, from https://encyclopedia.19141918-online.net/article/southern africa

Sundkler, B. \& Steed, C., 2000, A history of the Church in Africa, Cambridge University Press, Cambridge.

Thompson, L., 2000, The history of South Africa, Yale University Press, New Haven, CT.

United Nations Department of Economic and Social Affairs, Population Division, 2013, World migration in figures, viewed 28 May 2016, from https://www.oecd.org/els/ $\mathrm{mig} /$ World-Migration-in-Figures.pdf

Vilhanová, V.P., 2007, 'Christian missions in Africa and their role in the transformation of African societies', Asian and African Studies 16(2), 249-260.

Watson, R.L., 1991, The slave question: Liberty and property in South Africa, Witwatersrand University Press, Johannesburg.

Wilson, M., 1972, The interpreters (Third Memorial Dugmore Lecture), The 1820 Settlers National Monument Foundation, Grahamstown.

Wirgman, A.T., 2012, History of the English church and people in South Africa, Nabu Press, Charleston, SC.

Worden, S., 1985, Slavery in Dutch South Africa, Cambridge University Press, Cambridge. 